\title{
David Tuesday Adamo's Academic Context: Nigerian Biblical Studies Navigating between African Interpretive Concerns and Western Scholarly Traditions
}

\author{
KNUT HOLTER (VID SPECIALIZED UNIVERSITY)
}

\begin{abstract}
The essay focuses on some aspects of Nigerian biblical studies, that is, Prof David Tuesday Adamo's immediate academic context. The core question of the essay is how the balance between African interpretive concerns and Western scholarly traditions has developed over the last four decades in the Nigerian guild of critical biblical studies. First, the 1980s were characterised by a more or less Western dominance but it saw the beginning of an institutionally and hermeneutically self-conscious Nigerian biblical studies. Second, the early 2020s are still characterised by Western dominance but it sees an increasing interest for interpretive concerns as those voiced by Nigerian biblical scholars. Professor Adamo has been part of the Nigerian guild of biblical studies throughout these four decades and his academic publications serve as an illustration of the material.
\end{abstract}

KEYWORDS: African Initiated Churches, Biblical studies (African), Biblical studies (Western), Biblical studies (Nigerian), Cush, David Tuesday Adamo

\section{A INTRODUCTION}

A quarter of a century has passed since I met professor David Tuesday Adamoto whom this essay is dedicated, in deep appreciation - for the first time. We had been corresponding for a couple of years by means of airmail, the communicative genre of the time, and on his invitation I had come to Owerri, in the south-eastern part of Nigeria, to participate in the 1995 Annual Meeting of the Nigerian Association for Biblical Studies (NABIS).

Both the theme of the Annual Meeting and its venue were important, I think. The theme was "Biblical principles and moral foundation for Nigerian society," a theme that is typical of the self-understanding of NABIS in the 1990s. It saw itself as a contextually sensitive voice of justice and conscience amidst

* Submitted: 28/04/2021; peer-reviewed: 01/07/2021; accepted: 04/08/2021. Knut Holter, "David Tuesday Adamo's Academic Context: Nigerian Biblical Studies Navigating between African Interpretive Concerns and Western Scholarly Traditions," Old Testament Essays 34 no. 2 (2021): 353 - 369. DOI: https://doi.org/10.17159/23123621/2021/v34n2a3. 
Nigeria's political and social challenges and it highlighted themes such as "Biblical perspectives to leadership role in nation building" (Annual Meeting 1991), "Biblical perspectives on ethics and morality in nation building" (Annual Meeting 1992) and "Christianity and economic emancipation in Africa with special focus on Nigeria" (Annual Meeting 1998). ${ }^{1}$ Adamo's contribution to the 1995 theme was - not surprising, as the the 1990s was Adamo's decade of reflecting on the Old Testament portrayal of the African nation of Cush - "EbedMelech's sense of moral judgment (Jer. 38:7-13 and 39:15-17): A challenge to Nigerian/African Christian leaders."

As for venue of the conference, NABIS had chosen Wesley International Bible College, an institution for the training of pastors and evangelists that had been established a few years earlier in Owerri by an American missionary. The college later relocated to Lagos and is today known as West Africa Theological Seminary, an institution with a strong commitment to serve church and society in Africa. Back in the mid-1990s, however, the American influence was still very visible, for example, the library, which in its entirety had been inherited from a seminary in the USA that had closed down - the books represented typically Western theological experiences and concerns with little attention to the immediate African context and the pictures on the walls showed beautiful scenery motifs, not from Imo State but from Minnesota.

In hindsight, I realise that my first meeting with Adamo - in the contexts of the research profile of NABIS and the Western-influenced profile of the venue - to some extent may serve as an illustration of the efforts of Adamo and other NABIS members to develop a biblical studies that can be labelled "Nigerian" in a qualified meaning of the term. Hence, the question to be addressed in the following is: How has the Nigerian guild of biblical scholars over the last generation negotiated between "African interpretive concerns" and "Western scholarly traditions"? I will approach this question in three steps. First is a discussion of the relationship between African interpretive concerns and Western scholarly traditions in what can be seen as the "past" of today's Nigerian biblical studies, exemplified with some crucial aspects of the academic field and guild in the 1980s. Then, a discussion of the same relationship at the "present," the beginning of the 2020s will be carried out before a discussion of Professor Adamo's research contributions as an illustrative example of Nigerian-and indeed African-biblical studies.

\section{B THE PAST-THE 1980s}

As an example of "the past" of today's Nigerian biblical studies, I have chosen the 1980s, first, because more or less one generation has now passed since the 1980s, which means it should be possible to have some critical distance. Second

1 John O. Akao, "Nigerian Association for Biblical Studies," Bulletin for Old Testament Studies in Africa 8 (2000): 5-7. 
the 1980s actually saw what I have described elsewhere as a "breakthrough" of an African biblical studies, a breakthrough where Nigerian scholars and academic institutions played lead roles. ${ }^{2}$ Although there had been examples of critical biblical studies in Nigeria prior to the $1980 \mathrm{~s},{ }^{3}$ that decade clearly represented someting new. Let me briefly note-and I will come back to this later-that Nigeria in the 1980s saw the development of academic structures like postgraduate programs and professional networks for biblical studies and likewise saw a new concern for letting African experiences be used actively and consciously as interpretive resources. In other words, it is possible to talk about a Nigerian biblical studies in a qualified way from the 1980 s on.

Let me start with some reflection on the influence of "Western scholarly traditions" in relation to Nigerian biblical studies in the 1980s. Generally speaking, I tend to think that the most important characteristics of the Western influence was that it was more or less taken for granted and I will note briefly two aspects of this. The first aspect is that the academic discipline of biblical studies at the time was generally understood in Western terms and concepts. To "do" biblical studies - as we often say — was simply understood as reading the biblical texts from certain typically Western historical and literary perspectives. Biblical studies was of course not the only academic discipline that understood itself in that way, it was part of a much broader interpretive paradigm that could (and can) be found throughout the humanities. Still, biblical studies is an important example of this broader interpretive paradigm because of the assumed normative status of its textual material and implicitly also normative, interpretive consequences of the Western influence.

Admittedly, in the 1980s, one could observe some cracks in this massive paradigm. Though, only cracks, for all practical purposes, the paradigm itself survived and to some extent still survives. In the early 1990s, in his now classic monograph Models of Contextual Theology, Stephen B. Bevans argued that "There is no such thing as "theology'; there is only contextual theology." of Bevans' contemporary Western colleagues would actually have said the opposite. There is such a thing as theology, they would say, namely the kind of critical theology that is performed in the West. Then, there is contextual theology

\footnotetext{
2 Knut Holter, Contextualized Old Testament Scholarship in Africa (Nairobi: Acton, 2008), 99-110.

3 See for example Boniface A. Osuji, "The Hebrew and Igbo Concept of Religion and Sin Compared in the Light of Biblical and Rabbinic Literature" (DTh thesis, Pontifical Urban University, Rome), 1967; John Onaiyekan, "The Priesthood among the Owe-Yoruba of Nigeria and in Pre-monarchical Ancient Israel: A Comparative Study" (DTh thesis, Pontifical Urban University, Rome), 1975; Francis O. Ugwueze, "Igbo Proverbs and Biblical Proverbs: Comparative and Thematic Research" (DTh thesis, Pontifical Urban University, Rome), 1976.

4 Stephen B. Bevans, Models of Contextual Theology (Maryknoll: Orbis Books, 2002), 3.
} 
namely the kind of theological reflection that is performed in the younger churches in Africa, Asia and Latin America and in the academic institutions in their contexts.

Similar concepts were also found within the contemporary discipline of critical biblical studies. First, as far as interpretive approaches were concerned, the Western guild of biblical studies distinguished - if not in theory then at least in practice-between biblical studies per se and the more practical or applied approach, contextual biblical studies. The former referred to historical and literary studies of the biblical texts as developed over the centuries in Western interpretive communities, whereas the latter referred to studies that included contemporary and mainly extra-Western experiences and concerns in the interpretation. Let it be emphasised that this distinction did not reflect a deliberate marginalisation of biblical interpretation outside the Western context. Rather, it reflected what we today see as blind spots vis-à-vis the encounter between interpreter and text. An illustrative example is Volker Küster's monograph The Many Faces of Jesus Christ: Intercultural Christology, ${ }^{5}$ which analysed "contextual" interpretations of Jesus from African, Asian and Latin American perspectives. It is in many ways an excellent study. Nevertheless, in spite of its good intentions, its plot of presenting contextual interpretations by "others" actually results in ignoring the obvious fact that traditional Western faces of Jesus, too, are "contextual." As such, the book is representative of a biblical studies that sees (and offers a good analysis of) the contextuality of "others," but does not acknowledge its own contextuality.

The second aspect I would like to note is that a biblical studies that was understood according to Western terms and concepts actually required Western logistics and infrastructure as far as library services are concerned. With the exception of a few university libraries in South Africa-which in the 1980s were still influenced by the last spasms of apartheid - there were simply no university or seminary libraries in Africa that could provide researchers with the scholarly literature deemed necessary for a kind of biblical studies modelled according to Western scholarly concepts.

Consequently, biblical studies was in the 1980s basically conceptualised and constructed as a Western "thing," also in African universities and seminaries. One could of course have thought that this Western focus was a Western bias only. However, according to the doyen of New Testament studies in Nigeria, Samuel O. Abogunrin, the Western bias also characterised the first generation of African biblical scholars. Abogunrin argues:

5 Volker Küster, The Many Faces of Jesus: Intercultural Christology (Maryknoll: Orbis Books, 1999). 
Most of the African Biblicists are trained in the West and even those few ones trained in the continent are trained under Western influence. Unfortunately, most of these scholars on their return to Africa have always seen themselves as ambassadors of Cambridge, Oxford, Tübingen School, etc. or disciples of R. Bultmann, C.H. Dodd, Karl Barth etc. or of their Professors. They take joy in displaying the theological ideas they have just acquired from Europe or America. ${ }^{6}$

It is not difficult to understand these African biblical scholars who were sent to Europe and America to do postgraduate studies and there had to cope with an overwhelming tradition of texts and interpretations, theories and hermeneutics. Today's talk of "Western" versus "African" approaches to biblical studies probably expresses a rather anachronistic dichotomy in relation to the 1980s, a decade where the interpretive contrasts would instead have been historical versus literary or textual versus empirical approaches. Hence, I have sympathy with those postgraduate African students striving to survive in a foreign context and returning as ambassadors of new ways of reading the biblical texts.

However, there was another option, the task of initiating an African biblical studies that could be characterised not so much by Western interpretive traditions and strategies as by religious, cultural and social experiences and concerns of contemporary Africa, that is, a biblical studies that with some justification could be labelled "African." Nigerian biblical scholars and institutions played a major role here and let me note briefly three important initiatives in this regard. The first was the Nigerian focus on establishing academic frameworks for theology and biblical studies. A number of state and federal universities in Nigeria have institutional structures for religious studies; actually, more than any other country in Africa. From the 1980s on, this created a need for university scholars with a biblical studies background. In my analysis of Old Testament doctoral theses written by African scholars between 1967 and 2000, as many as 34 of a total number of 87 are written by Nigerians. ${ }^{7}$ Most of these theses were researched and defended in Western contexts (Catholics preferred Rome, Evangelicals preferred the USA) but in the early 1980s the federal universities in Ibadan and Nsukka - as the first ones on the African continent, with the exception of some traditional South African universitiesestablished their own PhD programs in biblical studies (cf. Gabriel Abe, 1983, in Ibadan and D.J.I. Ebo, 1985, in Nsukka). ${ }^{8}$

6 Samuel O. Abogunrin, "Biblical Research in Africa: The Task Ahead," African Journal of Biblical Studies 1 (1986): 13.

7 Knut Holter, Old Testament Research for Africa: A Critical Analysis and Annotated Bibliography of African Old Testament Dissertations, 1967-2000 (New York: Peter Lang, 2002), 65.

8 Gabriel Abe, "Covenant in the Old Testament" (PhD thesis, University of Ibadan), 1983; D.J.I. Ebo, "'O that Jacob Would Survive': A Study of Hope in the Book of Amos" (PhD thesis, University of Nigeria, Nsukka), 1985. 
The second initiative for creating a context for an Africanised biblical studies was the 1978 establishing of the Panafrican Association of Catholic Exegetes (PACE). The organisation aimed at bringing Catholic biblical scholars together to reflect on the encounter between African contexts and biblical texts and at finding a balance between exegetical approaches (which in practice meant quite traditional Western approaches) and African contextual concerns. ${ }^{9}$ PACE met in Kinshasa in 1978 (theme-African Christian identity: Exegetical perspectives) and in Ibadan in 1984 (theme-Acts and the young churches) and Nigerian biblical scholars and church leaders - such as (now: Cardinal) John Onaiyekan—-played important roles there. ${ }^{10}$

The third initiative was the 1986 establishing of the Nigerian Association for Biblical Studies (NABIS) and simultaneously a journal to be published by NABIS, African Journal of Biblical Studies. ${ }^{11}$ From the very beginning, both association and journal expressed a strategy with a similar balance as that of PACE; on the one hand "Promoting Biblical research in Africa and disseminating the result of the research" and "Promoting the study of Biblical and the related languages," but also on the other hand "Relating the interpretation of the Bible to the life situation in Africa and African societal problems" and "Encouraging Biblical scholars to look afresh at the Bible with an African insight, relating their interpretation to the past and the prevailing situation of the Church in Africa."12

The concerns expressed by establishing $\mathrm{PhD}$ programs and creating associations for biblical studies were further developed by the young generation of biblical scholars of the time. Let two examples from the Nigerian guild in the mid-1980s suffice to illustrate this. One is Emmanuel Nlenanya Onwu, whose 1985 article addressd the "current state of biblical studies in Africa." 13 Discussing themes such as liberation, mission, and Christology, he concludes that a conscious African approach has a particular contribution to make:

What perhaps is distinctive in our entire approach is the consideration of those themes in relation to the African's experience and selfunderstanding. In Africa, vulnerability and underdevelopment are basic. Coincidentally, these were also problems that angered Jesus in his own days. They should be the core concerns of Africans in biblical studies today... We biblical scholars cannot claim to have done our work well

\footnotetext{
9 André K. Mukenge, “Association Panafricain des Exégètes Catholiques," Bulletin for Old Testament Studies in Africa 8 (2000): 3-5.

10 Holter, Old Testament Research for Africa, 75-78.

11 Akao, "Nigerian Association," 5-7.

12 African Journal of Biblical Studies, Colophon Page of Volume 1/1 (1986).

13 Emmanuel N. Onwu, "The Current State of Biblical Research in Africa," Journal of Religious Thought 41 (1985): 35-46.
} 
until our new insights have been communicated with vital interest and power to congregations in our land and abroad. ${ }^{14}$

In other words, Onwu finds parallels between biblical concerns and current challenges in Africa which enable him to take a normative stance with regard to the scholarly strategies of African biblical studies. African biblical studies should make these parallels its "core concerns" and further, it has a responsibility to share its insights beyond academic and national borders.

Another example is Samuel O. Abogunrin, who in the policy article of 1986 referred to above argues that there is a need for a new approach to biblical studies in Africa. He asks: "In the light of African experience, can the present Western approach be the best for African Christianity?"15 His answer is then a balance between the Western interpretive tradition and the potential of a consciously contextualised African biblical studies. The latter would not only benefit the African interpretive communities, it would represent even more Africa's contribution to the more general interpretation of the Bible:

Undoubtedly, African Christianity has benefited tremendously from the cummulative labour of Western scholars. It has kept African Christians aware of the questions being raised about the Bible and which are pertinent to serious Biblical research today. At the same time, the increasing desire among some African scholars to make Biblical studies relevant should be seen as contributing to the history of enquiry into the nature and contents of the Bible. ${ }^{16}$

In a sum, the Nigerian biblical studies we can see back in the 1980s is characterised by the absence of balance between African interpretive concerns and Western influence. The Western scholarly tradition was overwhelming, although attempts at creating an Africanised version of the dicipline were made, a version that would allow African interpretive concerns to play some role in the interpretation of the biblical texts.

\section{THE PRESENT-THE EARLY 2020s}

How, then, is the situation of Nigerian biblical studies today, at the beginning of the 2020s? Much has actually changed. The PACE and NABIS initiatives referred to above have survived and have contributed much to the institutionalisation of a consciously African biblical studies. A large number of PhD-holding lecturers have been appointed, increasingly with doctorates from Nigerian universities and quite a number of postgraduate programs, too, have

\footnotetext{
14 Onwu, "The Current State," 46.

15 Abogunrin, "Biblical Research," 13.

16 Ibid.
} 
been established. ${ }^{17}$ Further, the reflections by Onwu and Abogunrin have been followed up by scholars in Nigeria and all over the continent. ${ }^{18}$

In my discussion above, I mentioned two aspects of how the Western influence was taken for granted in the 1980s version of African biblical studies and I would like to return to the two from a 2021 perspective. The first aspect is the observation that the academic discipline of biblical studies was generally understood in Western terms and concepts. In consequence, Western scholars would normally distinguish between biblical studies per se and contextual biblical studies, thereby, effectively marginalising the much more contextually focused African biblical studies as being outside a commonly accepted definition of the discipline.

Admittedly, already a generation ago, one could also in Western contexts see examples of a methodological and hermeneutical diversification of critical biblical studies, in a way that could open up for African experiences and concerns. This diversification has increased in the meantime and got more general acceptance and the result is that some of those approaches that were seen as "contextual" by Western scholars a generation ago are included today in their methodological and hermeneutical toolbox.

One example is the renewed focus on literary approaches in biblical studies, which from an African and indeed Nigerian interpretive perspective means that the wealth of traditional narrative, proverbial and other religious material can be used as interpretive resources. Some examples of biblical interpretations making use of this African material were available already in the $1980 \mathrm{~s}^{19}$ and many more studies of this kind have been produced in recent years by Nigerian scholars such as Solomon Ademiluka and Paschal Mbagwu. ${ }^{20} \mathrm{~A}$ second example was the introduction of social science models into Western models of biblical studies. From an African interpretive perspective, this meant that African traditional and contemporary societal experiences would be able to provide comparative material for biblical interpretation. Nigerian scholars provided examples of such interpretations already in the $1980 \mathrm{~s}^{21}$ and the approach has become more and more popular, as exemplified by the studies of

17 Holter, Contextualized, 83-115.

18 Andrew M. Mbuvi, "African Biblical Studies: An Introduction to an Emerging Discipline," Currents in Biblical Research 15 (2017): 149-178.

19 See for example Justin S. Ukpong, Sacrifice: African and Biblical: A Comparative Study of Ibibio and Levitical Sacrifices (Rome: Urbaniana University Press, 1987).

20 Solomon O. Ademiluka, Genesis 1-3 in an African Setting (Odo-Okun: Nathadex Publisher, 2008); Paschal C. Mbagwu, Where God and Human Meet: The Paschal Mystery, Priesthood and Sacrifice among the Igbos (Chicago: Crossroad, 2017).

21 Latunji G. Lasebikan, "Prophecy or Schizophrenia? A Study of Prohecy in the Old Testament and in Selected Aladura Churches" (PhD thesis, University of Ibadan), 1983. 
Joel Ajayi, Theophilus Ejeh and Gerald Umoren. ${ }^{22}$ A third example of the methodological and hermeneutical diversification of Western biblical studies that took place in the late 1980s was the acknowledgment of the ethical responsibility of doing public biblical interpretation, with Elizabeth Schüssler Fiorenza as a key exponent. ${ }^{23}$ This interpretive strategy already gained much attention in African - and not least Nigerian-bibical studies ${ }^{24}$ and it has continued to characterise Nigerian Old Testament scholarship, as we can observe both in the NABIS anthologies built on the Annual Meetings of NABIS - for example the 2006 meeting on corruption and the 2008 meeting on leadership ${ }^{25}$ and in a number of monographs such as that of Michael U. Udoekpo. ${ }^{26}$

In other words, the concepts of biblical studies and the contents of the interpreter's toolbox are changing. The interpretive models that characterised the discipline a generation ago (and earlier) — which in practice marginalised African biblical studies - have lost some of their scholarly monopoly, as they have been joined by interpretive models that emphasise quite different questions. This does not mean that all African and Nigerian Old Testament scholars make use of their Nigerian context as an explicit interpretive tool; some scholars decide to follow the lead of more traditional approaches, such as Cephas Tushima and Joel Biwul. ${ }^{27}$ However, they do have a choice; today there is an increasing room for African experiences and concerns also in Western versions of critical biblical

22 Joel A.A. Ajayi, A Biblical Theology of Gerassapience (New York: Peter Lang, 2010); Theophilus U. Ejeh, The Servant of Yahweh in Isaiah 52:13-53:12: A Historical Critical and Afro-Cultural Hermeneutical Analysis with the Igalas of Nigeria in View (Zürich: LIT Verlag, 2012); Gerald Umoren, The Experience of the Israelite Exiles in Psalm 137 Compared with the Displaced Persons in Nigeria Today: A Presentist Interpretation of the Bible (New York: Edwin Mellen, 2017).

${ }^{23}$ Elisabeth S. Fiorenza, "The Ethics of Biblical Interpretation: Decentering Biblical Scholarship," Journal of Biblical Literature 107 (1988): 3-17.

24 Knut Holter, "Ancient Israel and Modern Nigeria: Some Remarks from the Sidelines on the Socio-critical Aspect of Nigerian Old Testament Scholarship," in Yahweh in Africa: Essays on Africa and the Old Testament (ed. Knut Holter; New York: Peter Lang, 2000), 61-76.

25 Samuel O. Abogunrin, ed., Biblical Studies and Corruption in Africa (Ibadan: Nigerian Association for Biblical Studies, 2007); Samuel O. Abogunrin, ed., Biblical Studies and Leadership in Africa (Ibadan: Nigerian Association for Biblical Studies, 2009).

26 Michael U. Udoekpo, Rethinking the Prophetic Critique of Worship in Amos 5 for Contemporary Nigeria and the USA (Eugene: Pickwick, 2017).

27 Cephas T.A. Tushima, The Fate of Saul's Progeny in the Reign of David (Eugene: Pickwick, 2011); Joel K.T. Biwul, A Theological Examination of Symbolism in Ezekiel with Emphasis on the Shepherd Metaphor (Carlisle: Langham, 2013). 
studies and this situation makes a dialogue between African and Western versions of biblical studies easier. ${ }^{28}$

The second aspect of how the Western influence was taken for granted in the 1980s versions of African biblical studies was that a biblical studies being understood according to Western terms and concepts actually required Western logistics and infrastructure as far as library services are concerned. When seen from a 2021 perspective, things have here changed, as the accessability of research literature, therefore, also access to current research discourses, has improved significantly. The most high-profiled example is the current focus on "open access," a concept proceeding from the idea that research results that are funded by the community are common property. It aims at democratisation of access to at least some genres of research literature, currently the genre of journal articles. On the technical level, this is made possible, of course, by the digitalisation of all texts. For African biblical studies, this is obviously an advantage, as institutional lack of funding - preventing university and seminary libraries from subscribing to, hence, also reading current journal articles-is a hindrance which is gradually removed. This does not mean that all problems are solved but it is a step forward in the democratisation of access to research results.

A less profiled example, but one that still could mean a lot to African biblical studies, is provided by various kinds of transnational guild solidarity. Of particular importance here is the International Cooperation Initiative of the USbased Society of Biblical Literature, https://www.sblsite.org/InternationalCoopInitiative.aspx. This is a project that is intended to support the fostering of biblical studies in less privileged parts of the world. The project involves several means of sharing resources, the most important among them being the provision of free online PDF files of recent books in the field to scholars and students who otherwise may not have access to these resources. This service is open to persons living in countries with a per capita GDP (Gross Domestic Product) that is substantially lower than the average per capita GDP of the United States and the European Union, which is a requirement that is met by Nigeria. The importance of this example lies partly in its size and partly in the fact that the titles covered by the initiative are recent research contributions, representative of today's discourses, not the outdated and often biased stuff that was traditionally made accessible at no cost on the web. When I analysed the list in December 2020, I found that it includes no less than 675 titles, of which 48 percent were published between 2010 and 2020, 48 percent between 2000 and 2009 and 4 percent before 2000, mainly in the 1980s and 1990s.

In sum, the balance between African interpretive concerns and the influence of the Western scholarly tradition in African biblical studies has improved in the last generation, as the two key expressions of the Western

28 Knut Holter, "Does a Dialogue between Europe and Africa Make Sense?" in African and European Readers of the Bible in Dialogue: In Quest of a Shared Meaning (ed. Hans de Wit and Gerald O. West; Leiden: Brill, 2008), 69-80. 
marginalisation of African biblical studies of the 1980s-a narrow methodological and hermeneutical concept of the field, ignoring "contextual" concerns, and a Western economy with regard to library logistics and infrastructure-have lost some of their monopolistic power.

\section{ADAMO - BETWEEN THE 1980s AND THE EARLY 2020s}

The question is then what happened between the 1980s and the early 2020s. As mentioned above, I will use the research contributions of Professor David Tuesday Adamo to illustrate an answer to this question. However, before I come to Adamo, I would like to point out two theoretical perspectives.

The first one is the awareness we have today, more than in the 1980s, of how the colonial past continues to influence society, culture and even biblical interpretation. The awareness is based on the wave of postcolonial biblical interpretation in the $1990 \mathrm{~s}^{29}$ and it enables us to observe that the colonial paradigm of centre and margin continued, even in biblical studies and in spite of the political liberation of the 1960s. In Nigeria, the question of decolonising biblical studies was put on the aggenda at the 2004 Annual Meeting of NABIS ${ }^{30}$ and it was addressed by Adamo in his Inaugural Lecture at Delta State University the same year. ${ }^{31}$

The second theoretical perspective that I would like to point out is Justin S. Ukpong's establishing of a chronology of modern African biblical studies. ${ }^{32}$ Ukpong emphasises hermeneutical concerns and argues that three distinct phases can be identified: (i) a reactive phase (1930s-1970s), which searched to legitimise African religion and culture vis-à-vis the western tradition through comparative studies, (ii) a reactive-proactive phase (1970s-1990s), which more clearly made use of the African context as a resource for biblical interpretation and (iii) a proactive phase (1990s), which made the African context the explicit subject of biblical interpretation. In my view, Ukpong exaggerates the chronology; I tend to think that his three chronological phases are three more or less simultaneous approaches. Nonetheless, he is right in pointing out an increasing focus on the African context as an interpretive resource.

29 Fernando F. Segovia, Decolonizing Biblical Studies: A View from the Margins (Maryknoll: Orbis Books, 2000); Rasiah S. Sugirtharajah, ed., The Postcolonial Bible (Sheffield: Sheffield Academic Press, 1998).

30 Samuel O. Abogunrin, ed., Decolonization of Biblical Interpretation in Africa (Ibadan: Nigerian Association for Biblical Studies, 2005).

31 David T. Adamo, Decolonizing African Biblical Studies: The $7^{\text {th }}$ Inaugural Lecture of Delta State University, Abraka (Abraka: Delta State University, 2007).

32 Justin S. Ukpong, "Developments in Biblical Interpretation in Africa: Historical and Hermeneutical Directions," Journal of Theology for Southern Africa 108 (2000): $3-18$. 
Now, in an attempt to illustrate how the balance between African interpretive concerns and Western influence in African biblical studies developed during the last generation, I will use some research publications by Professor Adamo as examples. ${ }^{33}$

I will approach Adamo from two perspectives. The first is his contribution as a profiled researcher with a heavy list of publications. Adamo's research contributions can be split into two thematic groups and I think that both illustrate some crucial aspects of how the balance between African concerns and Western influence in African biblical studies have developed during the last generation. The first group contains his research on what he calls the African presence in the Bible. It started with his $1986 \mathrm{PhD}$ thesis at Baylor University on "The Place of Africa and Africans in the Old Testament and its Environment," later disseminated in a number of articles throughout the 1990s and finally also published as a monograph in 1998, Africa and Africans in the Old Testament. ${ }^{34}$ A few years later a companion volume entitled Africa and Africans in the New Testament was published. ${ }^{35}$ The main message of these early publications is that there is indeed an African presence in the Bible. One of Adamo's favourite anecdotes is about one of his American professors who accused him of smuggling Africa into the Bible, but this is not necessary, according to Adamo. Africa is already there in the Bible. In later publications he develops the concept of an African presence in more strategic directions for the academic discipline of Old Testament studies; it should influence the way the African institutions teach the history of Israel ${ }^{36}$ as well as the ways certain Old Testament bookssuch as Jeremiah - are to be presented. ${ }^{37}$

As far as a definition of the "African presence" in the texts are concerned, it is interesting to see that Adamo differentiates between the two testaments. His study of the Old Testament focuses mainly — though not only—on references to

33 For more than two decades, Adamo's publications have been analysed closely by colleagues within biblical studies. Illustrative examples are Marta Høyland [Lavik], "An African Presence in the Old Testament? David Tuesday Adamo's Interpretation of the Old Testament Cush Passages," Old Testament Essays 11/1 (1998): 50-58; Knut Holter, Contextualized, 70-74; Madipoane Masenya, "Professor David Tuesday Adamo's Biblical Scholarship on Women: Reflections from an African-South African Mosadi," Old Testament Essays 33/2 (2020): 348-362.

34 David T. Adamo, Africa and the Africans in the Old Testament (San Francisco: Christian Universities Press, 1998).

35 David T. Adamo, Africa and the Africans in the New Testament (Lanham: University Press of America, 2006).

36 David T. Adamo, "Teaching the History of Ancient Israel from an African Perspective: The Invasion of Sennacherib of 701 B.C.E. as an Example," Old Testament Essays 23/3 (2010): 473-501.

37 David T. Adamo, "The Portrayal of Africa and Africans in the Book of Jeremiah," In die Skriflig 52/1 (2018), a2259 | DOI: https://doi.org/10.4102/ids.v52i1.2259. 
the Cushites, the black neighbors of Egypt further south along the Nile, at the cost of the Egyptians. However, when he turns to the New Testament, he tones down the color aspect, instead widening the scope and including all references to geographical and cultural entities that can be located to the African continent.

In the present context, searching to understand how the balance between African concerns and Western influence in African-and in particular Nigerian-biblical studies developed during the last generation and with postcolonial theory and Ukpong's chronology as an interpretive compasses, I would like to higlight two points in Adamo's focus on the African presence in the Bible. The first is that he is able to disclose and deconstruct the negative, colonial portrayals of Africans present in the Bible, as they are attested in biblical commentaries from the 19th century and long into the 20th. The second is that he is able to counter this negative, interpretive tradition, showing that it has no support in biblical and extra-biblical sources. Without dialoguing explicitly with postcolonial theory, Adamo nevertheless illustrates one of its major concerns namely that the Western and colonial, interpretive milieu used biblical texts to create an "Africa" that fitted their colonial concerns.

The second group contains Adamo's research on interpretive strategies vis-à-vis the Bible in certain African Initiated Churches (AIC). In his 2001 monograph Reading and Interpreting the Bible in African Indigenous Churches ${ }^{38}$ Adamo analysed the role of biblical texts in the daily lives of believers in some of these churches. To take the Psalms as an example, he points out how texts from Psalms can be read-sometimes into water and oil, sometimes also with herbs and other ingredients - for therapeutic purposes or for protection or success in life. Adamo has here gone into a new field, previously to a large extent ignored by biblical scholars but now gaining some attention. ${ }^{39}$ One can hardly say that he keeps a critical distance to his informants, he is quite close. However, in this way he is able to produce a material and an interpretation that illustrate Ukpong's third phase, characterised by a focus not only on the African context as the subject of interpretation, but on a recognition of ordinary readers of the Bible (that is readers without a training in critical interpretation) also as important partners in the process of academic interpretation of the Bible. ${ }^{40}$ Adamo's predilection for Psalms has continued, and in the last decade he has published a number of studies where individual Psalms are read from Yoruba perspectives. $^{41}$

38 David T. Adamo, Reading and Interpreting the Bible in African Indigenous Churches (Eugene: Wipf \& Stock, 2001).

39 Knut Holter, "Pregnancy and Psalms: Aspects of the Healing Ministry of a Nigerian Prophet," Old Testament Essays 27/2 (2014): 428-443.

40 Ukpong, "Developments in Biblical Interpretation," 15.

41 David Tuesday Adamo, "Reading Psalm 35 in Africa (Yoruba) Perspective," Old Testament Essays 32/3 (2019): 936-955; David Tuesday Adamo, "The Poor in the 
My second perspective regarding Adamo is his participation in national and international guilds of biblical studies. The national examples are of course NABIS and African Journal of Biblical Studies, where he has served as chairperson of the former and editor of the latter. In both capacities he tried to create a dialogue between the Nigerian guild and guild members from other parts of the world. When I came to NABIS for the first time - at the Annual Meeting in Owerri in 1995 - it was at the invitation of Adamo and as part of his strategy of building networks for dialogue between African and Western scholarship. Likewise, Adamo has been a frequent participant in international guilds such as the Old Testament Society of South Africa (OTSSA), the International Organization for the Study of the Old Testament (IOSOT) and not least the Society of Biblical Literature (SBL).

In 2019, two of these organisations-NABIS and SBL-honoured Adamo with special sessions on his scholarship, allowing colleagues from the USA, Europe and Africa to discuss some of his scholarly concerns. Critically, of course, as it would be contrary to what he stands for-and indeed contrary to basic concepts of critical biblical studies - to think that Adamo has said the last word in these research fields. He has put some crucial questions on the agenda, questions that are important for understanding the Bible and for developing the academic discipline of critical biblical studies. Nonetheless, he has not said the last word; rather he has offered us-his fellow students of the Bible-an invitation to continue the discussion and strengthen the reflection.

\section{E CONCLUSION}

In this essay I have used some of Professor David Tuesday Adamo's contributions to critical biblical studies to illustrate a few aspects of how the balance between African interpretive concerns and the influence of the Western scholarly tradition has been negotiated in African — and in particular Nigerianbiblical studies in the last generation. As seen from a Nigerian perspective (if I as a European dare to do that), it seems that the balance has improved. It is indeed not difficult to find examples of a continuing marginalisation of African concerns, even in African biblical studies. At the same time-as vividly demonstrated by Adamo-neither is it difficult to see that we today with much more justification than a generation ago can talk about an African biblical studies, characterised by African interpretive concerns.

\section{F BIBLIOGRAPHY}

Abe, Gabriel. "Covenant in the Old Testament." $\mathrm{PhD}$ thesis, University of Ibadan, 1983.

Book of Psalms and in Yoruba Tradition," Old Testament Essays 27/3 (2014): 797815; David Tuesday Adamo "Decolonizing Psalm 91 in an African Perspective with Special Reference to the Culture of the Yoruba People of Nigeria," Old Testament Essays 25/1 (2012): 9-26. 
Abogunrin, Samuel O. "Biblical Research in Africa: The Task Ahead.” African Journal of Biblical Studies 1 (1986): 7-24.

ed. Decolonization of Biblical Interpretation in Africa. Ibadan: Nigerian Association for Biblical Studies, 2005.

. ed. Biblical Studies and Corruption in Africa. Ibadan: Nigerian Association for Biblical Studies, 2007.

. ed. Biblical Studies and Leadership in Africa. Ibadan: Nigerian Association for Biblical Studies, 2009.

Adamo, David T. Africa and the Africans in the Old Testament. San Francisco: Christian Universities Press, 1998.

. Reading and Interpreting the Bible in African Indigenous Churches. Eugene: Wipf \& Stock, 2001.

. Africa and Africans in the New Testament. Lanham: University Press of America, 2006.

. "Decolonizing African Biblical Studies." The $7^{\text {th }}$ Inaugural Lecture of Delta State University, Abraka, 2007.

. "Teaching the History of Ancient Israel from an African Perspective: The Invasion of Sennacherib of 701 B.C.E. as an Example." Old Testament Essays 23/3 (2010): 473-501.

. "Decolonizing Psalm 91 in an African Perspective with Special Reference to the Culture of the Yoruba People of Nigeria." Old Testament Essays 25/1 (2012): 9-26.

. "The Poor in the Book of Psalms and in Yoruba Tradition." Old Testament Essays 27/3 (2014): 797-815.

."The Portrayal of Africa and Africans in the Book of Jeremiah." In die Skriflig 52/1 (2018), a2259 | DOI: https://doi.org/10.4102/ids.v52i1.2259.

. "Reading Psalm 35 in Africa (Yoruba) Perspective." Old Testament Essays 32/3 (2019): 936-955.

Ademiluka, Solomon O. Genesis 1-3 in an African Setting. Odo-Okun: Nathadex Publisher, 2008.

Ajayi, Joel A.A. A Biblical Theology of Gerassapience. New York: Peter Lang, 2010.

Akao, John O. "Nigerian Association for Biblical Studies." Bulletin for Old Testament Studies in Africa 8 (2000): 5-7.

Bevans, Stephen B. Models of Contextual Theology. Maryknoll: Orbis Books, 2002.

Biwul, Joel K.T. A Theological Examination of Symbolism in Ezekiel with Emphasis on the Shepherd Metaphor. Carlisle: Langham, 2013.

Ebo, D.J.I. "'O that Jacob Would Survive': A Study of Hope in the Book of Amos." $\mathrm{PhD}$ thesis, University of Nigeria, Nsukka, 1985.

Ejeh, Theophilus U. The Servant of Yahweh in Isaiah 52:13-53:12: A Historical Critical and Afro-cultural Hermeneutical Analysis with the Igalas of Nigeria in View. Zürich: LIT Verlag, 2012.

Fiorenza, Elisabeth S. "The Ethics of Biblical Interpretation: Decentering Biblical Scholarship." Journal of Biblical Literature 107 (1988): 3-17.

Holter, Knut. "Ancient Israel and Modern Nigeria: Some Remarks from the Sidelines on the Socio-critical Aspect of Nigerian Old Testament Scholarship." Pages 6176 in Yahweh in Africa: Essays on Africa and the Old Testament. Edited by Knut Holter. New York: Peter Lang, 2000). 
- Old Testament Research for Africa: A Critical Analysis and Annotated Bibliography of African Old Testament Dissertations, 1967-2000. New York: Peter Lang, 2002.

.Contextualized Old Testament Scholarship in Africa. Nairobi: Acton Publishers, 2008.

. "Does a Dialogue between Europe and Africa Make Sense?" Pages 69-80 in African and European Readers of the Bible in Dialogue: In Quest of a Shared Meaning. Edited by Hans de Wit and Gerald O. West. Studies of Religion in Africa 32. Leiden: Brill, 2008.

. "Pregnancy and Psalms: Aspects of the Healing Ministry of a Nigerian Prophet." Old Testament Essays 27/2 (2014): 428-443.

Høyland, Marta. “An African Presence in the Old Testament? David Tuesday Adamo's Interpretation of the Old Testament Cush Passages." Old Testament Essays 11/1 (1998): 50-58.

Küster, Volker. The Many Faces of Jesus: Intercultural Christology. Maryknoll: Orbis Books, 1999.

Lasebikan, Latunji G. "Prophecy or Schizophrenia? A Study of Prophecy in the Old Testament and in Selected Aladura Churches." PhD thesis, University of Ibadan, 1983.

Manus, Chris U. "Elijah - a nabi' before the 'Writing Prophets': Some Critical Reflection." African Journal of Biblical Studies 1 (1986): 25-34.

Masenya (Ngwana Mpahlehle), Madipoane. "Professor David Tuesday Adamo's Biblical Scholarship on Women: Reflections from an African-South African Mosadi." Old Testament Essays 33/2 (2020): 348-362.

Mbagwu, Paschal C. Where God and Human Meet: The Paschal Mystery, Priesthood and Sacrifice among the Igbos. Chicago: Crossroad, 2017.

Mbuvi, Andrew M. "African Biblical Studies: An Introduction to an Emerging Discipline." Currents in Biblical Research 15 (2017): 149-178.

Mukenge, André K. "Association Panafricain des Exégètes Catholiques." Bulletin for Old Testament Studies in Africa 8 (2000): 3-5.

Onaiyekan, John. "The Priesthood among the Owe-Yoruba of Nigeria and in Premonarchical Ancient Israel: A Comparative Study." DTh thesis, Pontifical Urban University, Rome, 1975.

Onwu, Emmanuel N. "The Current State of Biblical Research in Africa." Journal of Religious Thought 41 (1985): 35-46.

Osuji, Boniface, A. "The Hebrew and Igbo Concept of Religion and Sin Compared in the Light of Biblical and Rabbinic Literature." DTh thesis, Pontifical Urban University, Rome, 1967.

Segovia, Fernando F. Decolonizing Biblical Studies: A View from the Margins. Maryknoll: Orbis Books, 2000.

Sugirtharajah, Rasiah S., ed.The Postcolonial Bible. Sheffield: Sheffield Academic Press, 1998.

Tushima, Cephas T.A. The Fate of Saul's Progeny in the Reign of David. Eugene: Pickwick, 2011.

Udoekpo, Michael U. Rethinking the Prophetic Critique of Worship in Amos 5 for Contemporary Nigeria and the USA. Eugene: Pickwick, 2017.

Ugwueze, Francis O. "Igbo Proverbs and Biblical Proverbs: Comparative and Thematic Research.” DTh thesis, Pontifical Urban University, 1976. 
Ukpong, Justin S. Sacrifice: African and Biblical: A Comparative Study of Ibibio and Levitical Sacrifices. Rome: Urbaniana University Press, 1987.

. "Developments in Biblical Interpretation in Africa: Historical and Hermeneutical Directions." Journal of Theology for Southern Africa 108 (2000): 3-18.

Umoren, Gerald. The Experience of the Israelite Exiles in Psalm 137 Compared with the Displaced Persons in Nigeria Today: A Presentist Interpretation of the Bible. New York: Edwin Mellen, 2017.

Knut Holter, Professor of Old Testament, Faculty of Theology, Diaconia and Leadership Studies, VID Specialized University, Stavanger, Norway. Extraordinary Professor, Stellenbosch University, South Africa. Email: knut.holter@vid.no. ORCID ID: https://orcid.org/0000-0001-6467-3325. 